\title{
Soil erosion vulnerability under scenarios of climate land-use changes after the development of a large reservoir in a semi-arid area
}

\section{Vera Ferreira, André Samora-Arvela \& Thomas Panagopoulos}

To cite this article: Vera Ferreira, André Samora-Arvela \& Thomas Panagopoulos (2016) Soil erosion vulnerability under scenarios of climate land-use changes after the development of a large reservoir in a semi-arid area, Journal of Environmental Planning and Management, 59:7, 1238-1256, DOI: $10.1080 / 09640568.2015 .1066667$

To link to this article: https://doi.org/10.1080/09640568.2015.1066667

\section{Published online: 07 Oct 2015.}

\section{Submit your article to this journal $\llbracket$}

Џ Article views: 187

View Crossmark data \lceil

Citing articles: 4 View citing articles $\square$ 


\title{
Soil erosion vulnerability under scenarios of climate land-use changes after the development of a large reservoir in a semi-arid area
}

\author{
Vera Ferreira, André Samora-Arvela and Thomas Panagopoulos (i) * \\ Research Centre for Spatial and Organizational Dynamics (CIEO), University of Algarve, \\ Campus de Gambelas, Faro, Portugal
}

(Received 4 January 2015; final version received 22 June 2015)

\begin{abstract}
Climate and land-use/cover changes (LUCC) influence soil erosion vulnerability in the semi-arid region of Alqueva, threatening the reservoir storage capacity and sustainability of the landscape. Considering the effect of these changes in the future, the purpose of this study was to investigate soil erosion scenarios using the Revised Universal Soil Loss Equation (RUSLE) model. A multi-agent system combining Markov cellular automata with multi-criteria evaluation was used to investigate LUCC scenarios according to delineated regional strategies. Forecasting scenarios indicated that the intensive agricultural area as well as the sparse and xerophytic vegetation and rainfall-runoff erosivity would increase, consequently causing the soil erosion to rise from $1.78 \mathrm{Mg} \mathrm{ha}^{-1}$ to $3.65 \mathrm{Mg} \mathrm{ha}^{-1}$ by 2100 . A backcasting scenario was investigated by considering the application of soil conservation practices that would decrease the soil erosion considerably to an average of $2.27 \mathrm{Mg} \mathrm{ha}^{-1}$. A decision support system can assist stakeholders in defining restrictive practices and developing conservation plans, contributing to control the reservoir's siltation.
\end{abstract}

Keywords: land-use change; soil erosion; Revised Universal Soil Loss Equation (RUSLE); scenarios; climate change; siltation; reservoir

\section{Introduction}

The rate of worldwide land-use changes and landscape structure modifications in recent decades has markedly increased as a consequence of anthropogenic pressure, including changes in agricultural technologies and social, political and economic development (Bakker et al. 2008). These changes have been associated with the loss of biodiversity, depletion of natural resources, and intensification of soil erosion (Kosmas et al. 1997; Yang et al. 2003; Blavet et al. 2009; Cantón et al. 2011; Leh, Bajwa, and Chaubey 2013; Wang and Shao 2013; Salvati and Colantoni 2015).

Soil erosion represents one of the most severe land degradation challenges, and climate change is expected to multiply the forces responsible for soil erosion, increasing the susceptibility of populations and their environments (Yang et al. 2003; Lal et al. 2011). Soil erosion is characterised by the decrease of soil depth and productivity, a consequence of runoff, which often causes damaging off-site impacts including sedimentation in rivers and reservoirs that result in their contamination and reduction of their usable lifetime (Pandey, Chowdary, and Mal 2007; Haregeweyn et al. 2013).

Over the past few decades, numerous advances have been made to assess soil erosion. Assessments typically involve the use of empirical models such as the Universal Loss

*Corresponding author. Email: tpanago@ualg.pt 
Equation (USLE) for small agricultural plots (Wischmeier and Smith 1978); conceptual models for complex terrain and large mountainous watersheds including Revised Universal Soil Loss Equation (RUSLE)-3D (Mitas and Mitasova 1998; Millward and Mersey 1999) and the USPED (Unit Stream Power-based Erosion Deposition) (Mitasova et al. 1996); or physically based models such as the ANSWERS (Areal Non point Source Watershed Environment Response Simulation) (Beasley, Huggins, and Monke 1980), WEPP (Water Erosion Prediction Project) (Nearing et al. 1989), and EUROSEM (European Soil Erosion Model) (Morgan et al. 1998). The empirical RUSLE (Renard et al. 1997) has been the most widely used model for estimating annual soil loss, primarily because of its structural simplicity, fewer input data requirements and the availability of parameter values (Volk, Möller and Wurbs 2010). The RUSLE is frequently combined with Geographic Information Systems (GIS) including geostatistical tools to model the spatial distribution of soil erosion (Terranova et al. 2009; Prasannakumar et al. 2012; Bhandari, Aryal, and Darnsawasdi 2015).

With regard to sustainable landscape planning, there is the challenge to promptly and efficiently study ecosystem changes and analyse their impacts. Scenario construction helps define dynamic plans and management approaches for the adequate adaptation to expected future occurrences (Wollenberg, Edmunds, and Buck 2000; Palacios-Agundez et al. 2013), and the decisions made according to the scenarios provide better flexibility when facing irreducible uncertainty (Peterson, Cumming, and Carpenter 2003). Scenarios may be built using forecasting and backcasting processes, with both procedures analysing the future state. A forecast begins with the current situation and likely future paths, and then anticipates an end-state (Schwartz 1996). First, the backcasting process delineates a desirable future and then looks backwards to the present to identify strategies and plans to achieve it, estimating the probability with which an adverse future can be avoided (Quist and Vergragt 2006).

Over the last few decades, numerous forecasting researchers have developed predictive models to understand the causes and impacts of land-use/cover changes (LUCC) (Veldkamp and Lambin 2001; Parker et al. 2003; Verburg et al. 2004; Koomen et al. 2007). These models are useful to explore the implications of possible future situations or directions (such as economic growth or ecological policy changes) on future land-use (Verburg et al. 2004; Yu et al. 2011). Usually the methods employed depend on the aim of the study and the level of complexity required; in some cases, multiple methods or techniques are adopted (Nainggolan et al. 2012). The multi-agent system models of landuse/cover change (MAS/LUCC models) have been widely used and usually combine a cellular automata model (CA) that represents the landscape with an agent-based model (ABM) to express the human interaction on the landscape (Parker et al. 2003).

The purpose of the study was to use the RUSLE model and test land-use and climate change forecasting scenarios for the semi-arid region of the Alqueva dam watershed, as a complementary way to investigate the impact of soil erosion on the lifetime of the reservoir. A decision support system was created using a backcasting scenario to help stakeholders develop site-specific soil conservation plans, issue restrictive regulations and identify soil management methods for the sustainable irrigation of the reservoir area's water supply.

\section{Study area}

The study area is situated in the Alentejo in the south of Portugal $\left(7^{\circ} 30^{\prime} \mathrm{W}, 38^{\circ} 15^{\prime} \mathrm{N}\right)$, a semi-arid region that has a history of strong desertification. In the 1950s, the notion of lack of productivity in south Portugal was related to the preponderance of non-irrigated 
agriculture, and the proposed solution was the establishment of the Alqueva dam on the Guadiana River (Sanches and Pedro 2007).

Initiated in 1998, the Alqueva dam created the largest artificial reservoir in Western Europe with a total surface area of $250 \mathrm{~km}^{2}$ (35 $\mathrm{km}^{2}$ of which is inside Spain), a total capacity of $4.15 \mathrm{~km}^{3}$, a total shoreline of approximately $1,100 \mathrm{~km}$ and an extension $83 \mathrm{~km}$ in length (Lindim, Pinho, and Vieira 2011). The strategic project had as its main objective the creation of a water reserve particularly for agriculture, energy production and human consumption. A general irrigation system of approximately 120,000 ha is mostly projected downstream from the Alqueva dam (92\%); however, the adjacent area upstream has an increasing number of irrigated agricultural areas due to the water being pumped directly from the Alqueva reservoir.

Excluding the submerged area, the research area consists of the territory of the landscape management plan that is specifically focused on the Alqueva reservoir's surroundings (CCDRA 2001), which integrates six municipalities of the region: Alandroal, Barrancos, Moura, Mourão, Portel and Reguengos de Monsaraz (Figure 1).

Demographically, the Alentejo region has been marked by a declining population, a result of a rural exodus, having lost $20 \%$ of its population between 1950 and 1960 (Sanches and Pedro 2007). The current population loss continues at a $9 \%$ rate for the 2001-2011 period (Panagopoulos and Barreira 2012).

The climate is continental Mediterranean (type Csa, according to Koppen classification), with mild winters and very hot and dry summers (Sanches and Pedro 2007). The average temperature ranges from 24 to $28^{\circ} \mathrm{C}$ in hot months (July/August) and from 8 to $11^{\circ} \mathrm{C}$ in cold months (December/January). The average annual precipitation for the last 30 years is approximately $500 \mathrm{~mm}$. The region is subjected to long dry periods, as $80 \%$ of the precipitation occurs from October to April (Ferreira and Panagopoulos 2014).

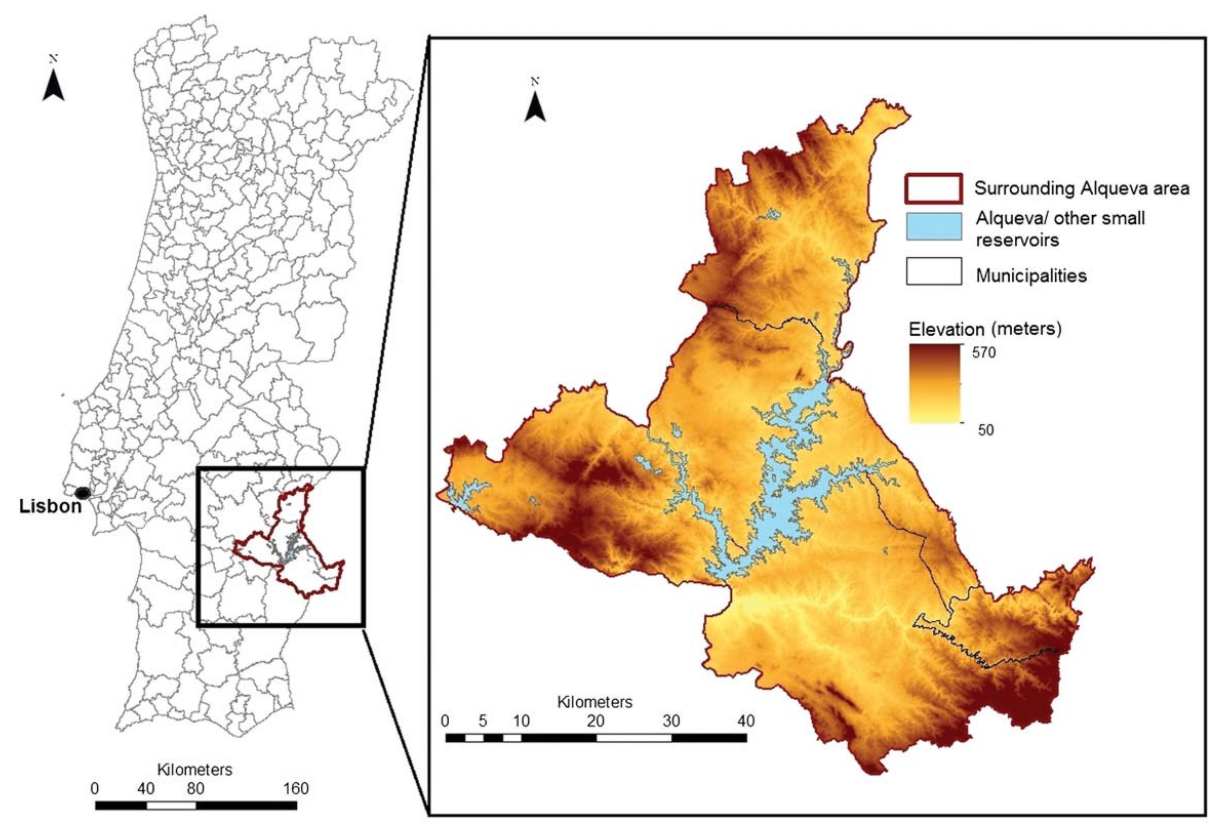

Figure 1. Map of the Alqueva reservoir's surrounding area according to regional landscape management plans. (See online colour version for full interpretation.) 
The soils are primarily leptosols and luvisols (FAO 2006) with a low percentage of organic matter. The landscape is characterised by its hilly topography with significant altitude variations (mostly between 50 and 570 metres). Before the dam's construction, the Alqueva landscape was characteristically dry and vast, reflecting the preponderance of non-irrigated agriculture, olive groves, vineyards and a typical agro-silvo-pastoral system known as "Montado" in Portugal and "Dehesa" in Spain. The traditional "Montado" is comprised of low-density woodlands that consist of cork oak (Quercussuber) and holm oak (Quercus ilex) combined with a rotation of crops/fallow/pastures (Borges et al. 2010). In some "Montado" areas, oaks are mixed with olive trees. In the beginning of the 20th century, there was an intensification of agriculture for cereal production in combination with extensive livestock breeding. Because of socioeconomic drivers, as presented by Jones et al. (2011), the abandonment of agricultural land increased at the end of the 20th century, with the transition of some "Montado" systems to silvo-pastoral or total forestry systems. Currently, the Alqueva landscape is rapidly changing as a consequence of water availability, resulting in land-use change dynamics due to the intensification of irrigated farming (Ferreira et al. 2015b). Furthermore, several tourism developments and golf resorts around the large lake are projected to drive rural tourism, and there are plans for biomass production for bioenergy. In addition to these land-use changes, further climate change is expected to modify vegetation patterns in that region.

\section{Material and methods}

To obtain the different scenarios of soil erosion (forecasting if the current situation will continue and backcasting if sustainable land management practices will be applied), the RUSLE model was applied to the entire study area.

\subsection{Soil erosion by RUSLE}

The RUSLE model is expressed as A = RKLSCP, where A is the potential erosion (annual average soil loss in $\mathrm{Mg} \mathrm{ha}^{-1}$ year $^{-1}$ ), $\mathrm{R}$ is the rainfall-runoff erosivity factor, $\mathrm{K}$ represents the soil erodibility factor, $\mathrm{L}$ and $\mathrm{S}$ are the topographic factors of the slope length and gradient, respectively, $\mathrm{C}$ is the vegetation cover factor, and $\mathrm{P}$ is the conservation practice factor.

Each of the RUSLE factors were effectively analysed using data on the GIS environment, and a graphical interpretation of those factors was performed with the use of geostatistics (Panagopoulos et al. 2006; Ferreira et al. 2015a). For the current situation, not accounting for land-use/cover changes, climate change or the implementation of support practices, these factors were computed as subsequently described. Given the limited availability of data, the current situation was established for 2006.

\subsection{1. $R$ factor}

The rainfall-runoff erosivity factor $(\mathrm{R})$, which represents the erosive impact of raindrops and the runoff produced by erosive storms, is estimated from the sum of the erosive rainstorm values EI30 occurring during a mean year, which is the product of the total storm kinetic energy (E) times the maximum 30 minute intensity (I30), where $\mathrm{E}$ is in $\mathrm{MJ} /$ ha and $\mathrm{I} 30$ is in $\mathrm{mm} / \mathrm{h}$ (Renard et al. 1997). The methodology described by Panagopoulos and Antunes (2008) was used in the present study to obtain a prediction map with annual values of rainfall erosivity. The daily precipitation values for 30 years (1979/80-2008/ 
09) were collected to accommodate the apparent cyclical rainfall patterns (Wischmeier and Smith 1978).

\subsubsection{Kfactor}

The soil erodibility factor $(\mathrm{K})$ denotes the susceptibility of the soil to be eroded, described by Renard et al. (1997) as the average amount of soil loss per unit of rainfall, provided by the erosivity index from a continuous cultivated fallow on a $9 \%$ slope that is $22.1 \mathrm{~m}$ long. Based on the RUSLE literature, the $\mathrm{K}$ factor is a measureable value estimated experimentally using an algebraic approximation, accounting for soil property values, typically obtained through soil survey data. For the needs of the present study a highresolution map $(500 \mathrm{~m})$ of soil erodibility in the European Union member states was used (Panagos et al. 2014). The values were calibrated with data obtained from small subwatersheds in the Alqueva area (Ferreira, Panagopoulos, and Cakula 2013).

\subsubsection{LS factor}

The RUSLE accounts for the topography considering the slope length (L) and steepness (S) factors. Both factors are designed for small agricultural fields and are not suitable for complex terrain. The use of a digital elevation model (DEM) in GIS is a better approach for the regional scale because it incorporates the impact of flow convergence considering the upslope contributing area per unit width at a point instead of the length (Desmet and Govers 1996). Therefore, in the present study, a DEM from the region was used in ArcGIS software to estimate this factor. GIS analyses allow one to generate slope steepness (S) and slope length (L) raster covers. The combined LS factor was computed for the watershed by means of the ArcGIS spatial analyst extension using the methodology described by Ferreira and Panagopoulos (2014).

\subsubsection{C factor}

The $\mathrm{C}$ factor considered by the RUSLE model represents the effect of vegetation on the erosion rate (Renard et al. 1997), which is essential to protecting soil by decreasing the raindrop energy before it meets the soil. $\mathrm{C}$ factor values diverge from 0 (well-protected soil) to 1 (bare soil) and there is a strict relation with land-use types. The $\mathrm{C}$ factor was analysed using corine land cover (CLC) data (IGEO 2012), as it facilitated the study of future land-use changes. The CLC provides information on the land cover using specific classes, and the most recent data are from 2006. The $\mathrm{C}$ factor values were assigned according to Wischmeier and Smith (1978) and Morgan (2005) (Table 1).

\subsubsection{P factor}

The conservation practice factor $P$ represents the influence of control practices, including contouring, strip cropping, and terracing, in soil erosion prevention by decreasing the amount of water runoff. These techniques can be referred to as sustainable land management (SLM) practices because they ensure soil conservation. The $P$ factor was assigned to be 1 (no support practice factor) because the control practices are insignificant in this area. 
Table 1. Corine land cover (CLC) classes present in the study area and their respective $\mathrm{C}$ factor mean values $\mathbb{C}[$ Wischmeier and Smith 1978; and Morgan 2005].

\begin{tabular}{|c|c|c|}
\hline CLC Class & Class Description & C Factor \\
\hline 111 & Continuous urban fabric & 0 \\
\hline 112 & Discontinuous urban fabric & 0 \\
\hline 121 & Industrial or commercial units & 0 \\
\hline 133 & Construction sites & 1 \\
\hline 142 & Sport and leisure facilities & 0.05 \\
\hline 211 & Non-irrigated arable land & 0.1 \\
\hline 212 & Permanently irrigated land & 0.2 \\
\hline 221 & Vineyards & 0.25 \\
\hline 222 & Fruit trees and berry plantations & 0.25 \\
\hline 223 & Olive groves & 0.25 \\
\hline 231 & Pastures & 0.1 \\
\hline 241 & Annual crops associated with permanent crops & 0.1 \\
\hline 242 & Complex cultivation patterns & 0.1 \\
\hline 243 & $\begin{array}{l}\text { Land principally occupied by agriculture, with significant areas of } \\
\text { natural vegetation }\end{array}$ & 0.1 \\
\hline 244 & Agroforestry areas & 0.06 \\
\hline 311 & Broad-leaved forest & 0.0015 \\
\hline 312 & Coniferous forest & 0.0025 \\
\hline 313 & Mixed forest & 0.002 \\
\hline 321 & Herbaceous natural grassland & 0.01 \\
\hline $321 \mathrm{a}$ & Sparse herbaceous vegetation and/or bare land & 0.15 \\
\hline 323 & Sclerophyllous vegetation & 0.003 \\
\hline $323 a$ & Xerophytic vegetation & 0.1 \\
\hline 324 & Transitional woodland/shrub & 0.003 \\
\hline $324 \mathrm{a}$ & Xerophytic vegetation & 0.1 \\
\hline 512 & Water bodies & 0 \\
\hline $512 \mathrm{a}$ & $\begin{array}{l}\text { Water bodies originated by the construction of small dams after } \\
2006\end{array}$ & 0 \\
\hline
\end{tabular}

\subsection{Forecasting scenarios}

A soil erosion forecasting scenario for the year 2100 was constructed using the RUSLE methodology, accounting for the effects of further climate change, which affects rainfallrunoff erosivity ( $\mathrm{R}$ factor) and vegetation cover ( $\mathrm{C}$ factor), and the LUCC scenarios, which affect vegetation cover ( $\mathrm{C}$ factor). The next subsections describe the methodology used to analyse the forecasted climate change and LUCC scenarios.

\subsubsection{Climate change}

Climate change is likely to modify the global and regional patterns of precipitation and temperature. Climate change scenarios have been produced for decades at a global and regional scale, driven by global circulation models (GCMs) and regional climate models (RCMs). According to the Hadley Centre Regional Model 2 (HadRM2) (Santos, Forbes, and Moita 2002), in the Alqueva area the total amount of precipitation is expected to decrease by $11 \%$ and temperatures are expected to increase $5.9^{\circ} \mathrm{C}$ by the year 2100 . Precipitation might be concentrated in winter months, decreasing more noticeably during 
summer and autumn, and an increase in the total number of days with more than $50 \mathrm{~mm}$ rainfall by 2100 (Santos, Forbes, and Moita 2002).

Modifications in precipitation amounts and intensities are expected to affect the rainfall-runoff erosivity values (the R factor of RUSLE) (Nearing, Pruski, and O'Neal 2004). Alpert et al. (2002) called foran intensification in the torrential rainfall despite a decrease in the predicted annual rainfall in the western Mediterranean region. For the south of Portugal, by 2100 , it is likely that an increase in the annual runoff between 0 and $50 \%$, associated with a strong rainfall intensity caused by precipitation concentrated in a small number of events, will occur according to Santos, Forbes, and Moita (2002). Considering these values, a mean increase in the rainfall-runoff erosivity of $12.5 \%$ for 2100 was considered when developing the future (forecasting and backcasting) soil erosion vulnerability scenarios for the study area.

As a consequence of the changes in precipitation patterns and temperature, the natural vegetation is equally expected to be altered in the region, due to the vulnerability of some species to extreme conditions. According to the future scenarios of the vegetation distribution in Portugal, developed according to ecosystem models, an increase of xerophytic and sparse vegetation in the study area is expected (Santos, Forbes, and Moita 2002). New classes were added while investigating the forecasting scenarios of the LUCC, accounting for the influence of climate changes on the existing land-use classes (CLC). The new classes are a result of the transition from 321 natural grassland to $321 \mathrm{a}$ sparse herbaceous vegetation and/or bare land; and 323 sclerophyllous vegetation and 324 transitional woodland/shrub to 323 a and 324 a xerophytic vegetation (Table 1). The increase of these classes was considered for areas with the most arid conditions, namely those with low annual precipitation values (between 400 and $500 \mathrm{~mm}$ ) and high temperatures (greater than 17.5\%).

\subsection{2. $L U C C$}

To analyse LUCC scenarios, a MAS was used. It combined a Markov chain (MC) and CA integrated model to analyse the spatial land-use patterns with a multi-criteria evaluation (MCE) to structure and aid decision-making processes.

The first phase of the LUCC investigation was the construction of the Markov transition matrices with IDRISI software (Clark University, Worcester, MA). The MC-CA integrated model is a common tool for modelling land-use change (Nainggolan et al. 2012). Markov analysis uses the historical pattern of land-use changes to calculate transition probabilities and determine the future land-use pattern (Tong et al. 2012; Kamusoko et al. 2009). The CLC maps from the years 2000 and 2006 were used as input data in the process to reflect the influence of water availability in land-use change. The use of CA in the Markov process with the IDRISI software allowed the spatial dimension to be added to the model, thereby capturing the temporal-spatial dynamics. In CA, a cellular entity is considered that changes between states (land-use types) according to the neighbouring conditions and adopts transition rules in a pre-defined time period (Verburg et al. 2004; Myint and Wang 2006). The produced transition matrices were used to build future scenarios.

To improve the performance of the previous technique for simulating the future LUCC, a second phase involving MCE was applied to incorporate the human factor. A MCE is useful to analyse the suitability for the potential transition of a certain area to maintain or change its land-use given the human intentions or objectives, revealing the influence and importance of each criteria (landscape factors and constraints) (Ligtenberg et al. 2004). In this research, the factors that were considered to affect the suitability of cells for the conversion into other land-use classes were as follows: the planning intentions of the 
regional and local landscape management plans (CCDRA 2001); topography; villages and historic components; proximity of conveniences; and constraints such as protected areas. These factors were analysed according to four potential future directions: biomass production for bioenergy, agricultural intensification, rural and golf tourism development, and the impact of climate change in vegetation cover. To achieve weights among these different criteria (factors), based on decisions and objectives for the study area, an analytical hierarchy process (AHP) was used for pairwise comparison of these factors (Saaty 2004; Chen, Yu, and Khan 2010). Specific weights were assigned to each factor (Arvela et al. 2012) and used in the computation of suitable maps in ArcGIS software.

The third part of the LUCC investigation was the combination of transition probabilities (2000-2006) and MCE suitable maps to assign LUCC in future landscaperelated scenarios (forecasting).

The LUCC scenarios were obtained for 2050 and 2100, accounting for the implications of these changes on soil erosion by the variation of RUSLE's C factor (referring to vegetation cover). The LUCC scenario for 2100 was included in the forecasting and backcasting scenario of soil erosion for the same year.

\subsection{Backcasting scenario}

The forecasting research improved the understanding of soil erosion vulnerability at the Alqueva watershed and the influence of different factors. This knowledge can be used as a basis to promote SLM and land-use planning in the Alqueva region. With that in mind, a backcasting scenario for 2100 was created, considering that an application of SLM practices would start immediately, particularly for those land uses that were projected to increase in the region (irrigated land, vineyards, fruit trees and olive groves, and sparse and xerophytic vegetation).

The backcasting scenario tempers expectations of future erosion vulnerability predictions and, along with backward inductions to the present, defines a desirable future with regards to soil erosion and sedimentation for the reservoir. Table 2 presents the common sustainable land-use practices considered for each land-use type and their respective P factor values according to Wischmeier and Smith (1978) and Morgan (2005).

\section{Results and discussion}

\subsection{Current situation}

Before the creation of forecasting scenarios, the current land-use and soil erosion situation in the area surrounding Alqueva dam was investigated. Figure 2 illustrates landuse according to the CLC in 2006, the most recent data. For this scenario, most of the area was still typified as agroforestry (CLC class 244), non-irrigated arable land (CLC

Table 2. The $\mathrm{P}$ factor considered for the soil erosion scenario in 2100 considering the application of some sustainable land management practices. @[ [Wischmeier and Smith 1978; Morgan 2005].

\begin{tabular}{|c|c|c|c|}
\hline CLC class & Class description & Conservation practice & $\mathrm{P}$ factor \\
\hline 212 & Irrigated land & Contouring & 0.5 \\
\hline 221,222 and 223 & $\begin{array}{l}\text { Vineyards, fruit trees, olive groves } \\
\left(\text { mean slope between } 2^{\circ} \text { and } 5^{\circ}\right)\end{array}$ & Contouring + strip-cropping & 0.25 \\
\hline $323 a$ and $324 a$ & Xerophytic vegetation & Afforestation (more $50 \%$ cover) & 0.5 \\
\hline
\end{tabular}




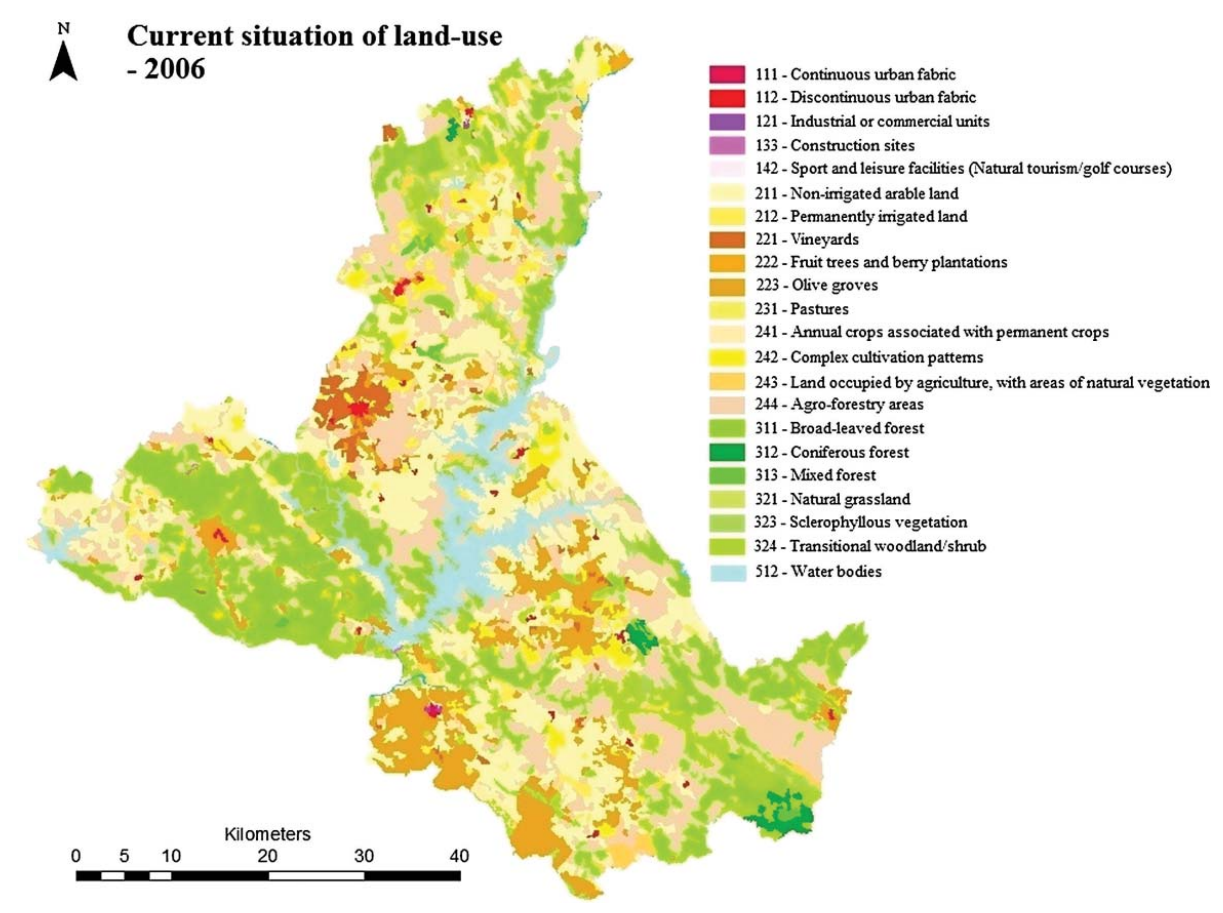

Figure 2. Land use in 2006 according to the corine land cover. (See online colour version for full interpretation.)

class 211) and olive groves (CLC class 223), the typical land-use types in the Alentejo region (Borges et al. 2010; Jones et al. 2011) until the challenges created by water availability from the Alqueva reservoir developed.

Figure 3 illustrates the soil erosion rates estimated using the RUSLE model for 2006, considering the land-use classes represented in Figure 2. The estimated annual mean value of soil erosion for 2006 was $1.78 \mathrm{Mg} \mathrm{ha}^{-1}$, and the highest values were associated with olive grove plantations (CLC class 223) located at high altitudes (Figure 1) with a high LS factor (steep and long slopes).

Considering frequent tillage was performed to control weeds in the olive groves, a practice which contributes to increased soil loss, a conversion from agroforestry land-use to olive groves may increase the soil loss to the reservoir. As previously reported by Ferreira and Panagopoulos (2014), the 'hot spots' of soil erosion for the study area were located on the agroforestry land-use area, reaching in some places an annual soil erosion rate that was greater than $30 \mathrm{Mg} \mathrm{ha}^{-1}$, mostly due to the combination of a steep slope, reduced vegetation cover and poor soils. Other small areas also exhibited high soil erosion values as a result of tourist resort development activities, where soil is frequently bare during the construction phase.

\subsection{Forecasting scenarios}

\subsubsection{LUCC}

To obtain the transition probabilities used to build future LUCC scenarios, the changes on land-use classes between 2000 and 2006 were investigated. In terms of the area of land- 


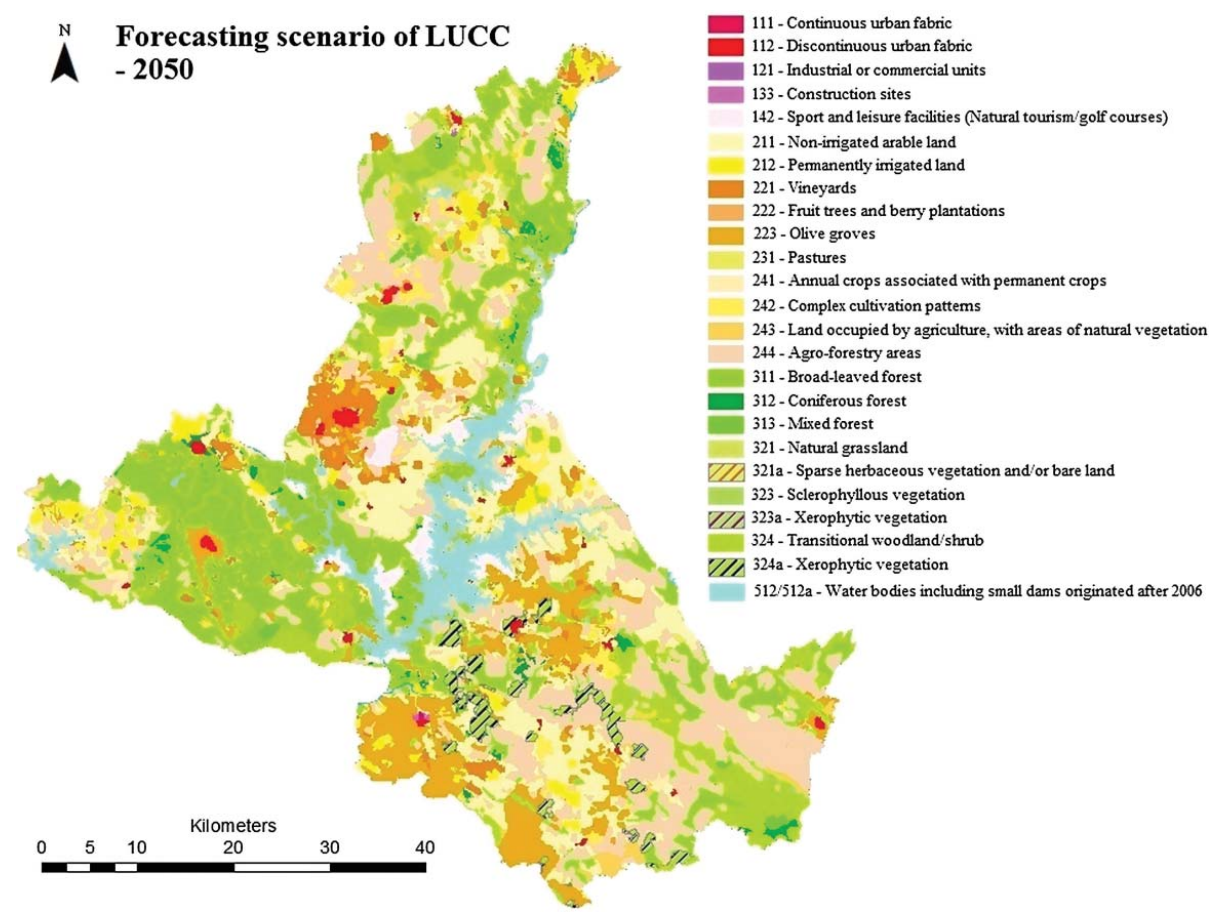

Figure 3. Forecasting scenario of the land-use/cover change for 2050. (See online colour version for full interpretation.)

use types, between these years the Alqueva landscape lost more than 4000 ha of broadleaved forest (CLC class 311) and approximately 3000 ha of non-irrigated arable land (CLC class 211). These quantitative land-use changes (2000-2006), estimated using the Markov transition matrix, are presented in Table 3. The decreased area of these land-use types is largely associated with an increase in transitional woodland/shrub (CLC class 324) land. Nevertheless, a percentage of these losses was associated with gains in agroforestry land area (CLC class 244), permanently irrigated land (CLC class 212) and vineyards (CLC class 221).

The forecasting LUCC scenarios for 2050 and 2100 were produced based on the transition matrix of the LUCC between 2000 and 2006, the definition of factors (decision-making agents) and their weight according to the different potential trajectories of land-use change (production of biomass for bioenergy, agricultural intensification by means of irrigation, increasing rural tourism and the development of golf resorts, and climate change). Figures 4 and 5 represent these forecasted land-use scenarios for 2050 and 2100 , respectively. The achieved changes are quantitatively described (in hectares) in Table 3. The expected LUCCs for 2050 and 2100 (when compared with 2006) are as follows:

- An increase in the discontinuous urban area (CLC class 112);

- A decrease in non-irrigated arable land (CLC class 211) and increase in permanently irrigated land (CLC class 212);

- An increase in sport and leisure facilities (natural tourism/golf courses) (CLC class $142)$ 
Table 3. Quantity of land-use change over time in hectares for each corine land cover (CLC) class, and the forecasting scenarios for 2050 and 2100 .

\begin{tabular}{|c|c|c|c|c|c|c|}
\hline \multirow[b]{2}{*}{$\begin{array}{l}\text { CLC } \\
\text { Class }\end{array}$} & \multicolumn{2}{|c|}{ Land use in past (ha) } & \multicolumn{4}{|c|}{ Land use in Scenarios (ha) } \\
\hline & 2000 & 2006 & BS 2050 & $\begin{array}{c}\text { Change } \\
\text { 2006/BS } 2050\end{array}$ & BS 2100 & $\begin{array}{c}\text { Change } \\
\text { 2006/BS 2100 }\end{array}$ \\
\hline 111 & 65.4 & 65.4 & 65.4 & 0 & 65.4 & 0 \\
\hline 112 & $1,300.4$ & 1,400 & $2,396.3$ & 996.3 & $2,396.3$ & 996.3 \\
\hline 121 & 107.8 & 126.9 & 127.4 & 0.5 & 127.4 & 0.5 \\
\hline 133 & 40.3 & 116.9 & 0 & -116.9 & 0 & -116.9 \\
\hline 142 & 0 & 0 & $5,824.4$ & $5,824.4$ & $6,777.6$ & $6,777.6$ \\
\hline 211 & $66,513.7$ & $64,330.6$ & $42,226.2$ & $-22,104.4$ & $42,111.7$ & $-22,218.9$ \\
\hline 212 & $3,248.2$ & $3,686.1$ & $9,976.1$ & 6,290 & $9,821.7$ & $6,135.6$ \\
\hline 221 & $4,587.1$ & 4,946 & $10,587.3$ & $5,641.3$ & $10,449.2$ & $5,503.2$ \\
\hline 222 & 437.1 & 425.5 & 448.6 & 23.1 & 448.9 & 23.4 \\
\hline 223 & $29,934.5$ & $30,063.6$ & $30,218.2$ & 154.6 & $30,132.1$ & 68.5 \\
\hline 231 & 504.4 & 467.9 & 253.2 & -214.7 & 253.2 & -214.7 \\
\hline 241 & $4,570.5$ & $4,552.3$ & $3,132.1$ & $-1,420.2$ & $3,104.7$ & $-1,447.6$ \\
\hline 242 & $8,868.4$ & $8,858.4$ & $6,229.7$ & $-2,628.7$ & $6,217.8$ & $-2,640.6$ \\
\hline 243 & $5,977.8$ & $5,991.8$ & $4,623.2$ & $-1,368.6$ & $4,623.2$ & $-1,368.6$ \\
\hline 244 & 69,306 & $70,609.5$ & $65,144.6$ & $-5,464.9$ & $65,036.4$ & $-5,573.1$ \\
\hline 311 & $59,374.6$ & $55,248.5$ & 62,207 & $6,958.5$ & $61,935.9$ & $6,687.4$ \\
\hline 312 & $2,648.1$ & $2,197.4$ & $2,753.1$ & 555.7 & $2,753.1$ & 555.7 \\
\hline 313 & 980.9 & 989.3 & $1,654.8$ & 665.5 & $1,654.7$ & 665.4 \\
\hline 321 & $2,036.1$ & $2,062.4$ & $1,423.6$ & -638.8 & 0 & $-2,062.4$ \\
\hline $321 \mathrm{a}$ & 0 & 0 & 131.7 & 131.7 & $1,538.9$ & $1,538.9$ \\
\hline 323 & $5,782.7$ & $5,239.5$ & $2,213.7$ & $-3,025.8$ & 0 & $-5,239.5$ \\
\hline $323 a$ & 0 & 0 & 26.1 & 26.1 & $2,239.8$ & $2,239.8$ \\
\hline 324 & $16,414.8$ & $21,320.8$ & $25,662.8$ & 4,342 & 0 & $-21,320.8$ \\
\hline $324 a$ & 0 & 0 & $5,186.7$ & $5,186.7$ & $30,824.2$ & $30,824.2$ \\
\hline $512 \mathrm{a}$ & 0 & 0 & 186.6 & 186.6 & 186.6 & 186.6 \\
\hline
\end{tabular}

- An increase in vineyards, olive groves, fruit trees and berry plantations (CLC classes 221, 222 and 223);

- A decrease in pastures, annual crops, complex cultivation patterns, agriculture with natural vegetation areas and agroforestry systems (CLC classes 231, 241, 242, 243 and 244);

- An increase in forested areas (CLC classes 311, 312, 313);

- A decrease in herbaceous natural vegetation (CLC class 321) and sclerophyllous vegetation (CLC class 323), and an increase in xerophytic vegetation and sparse vegetation (CLC class 321a, 323a and 324a);

- An increase in transitional shrub/woodland (CLC class 324) by 2050, and then a decrease until 2100.

These results reveal the influence of water availability on future land-use in the Alqueva region, which will permit the intensification of irrigated agricultural land. The region has already experienced an increase in the number of vineyards and olive groves implementing irrigation systems. For farmers faced with semi-arid conditions and the 


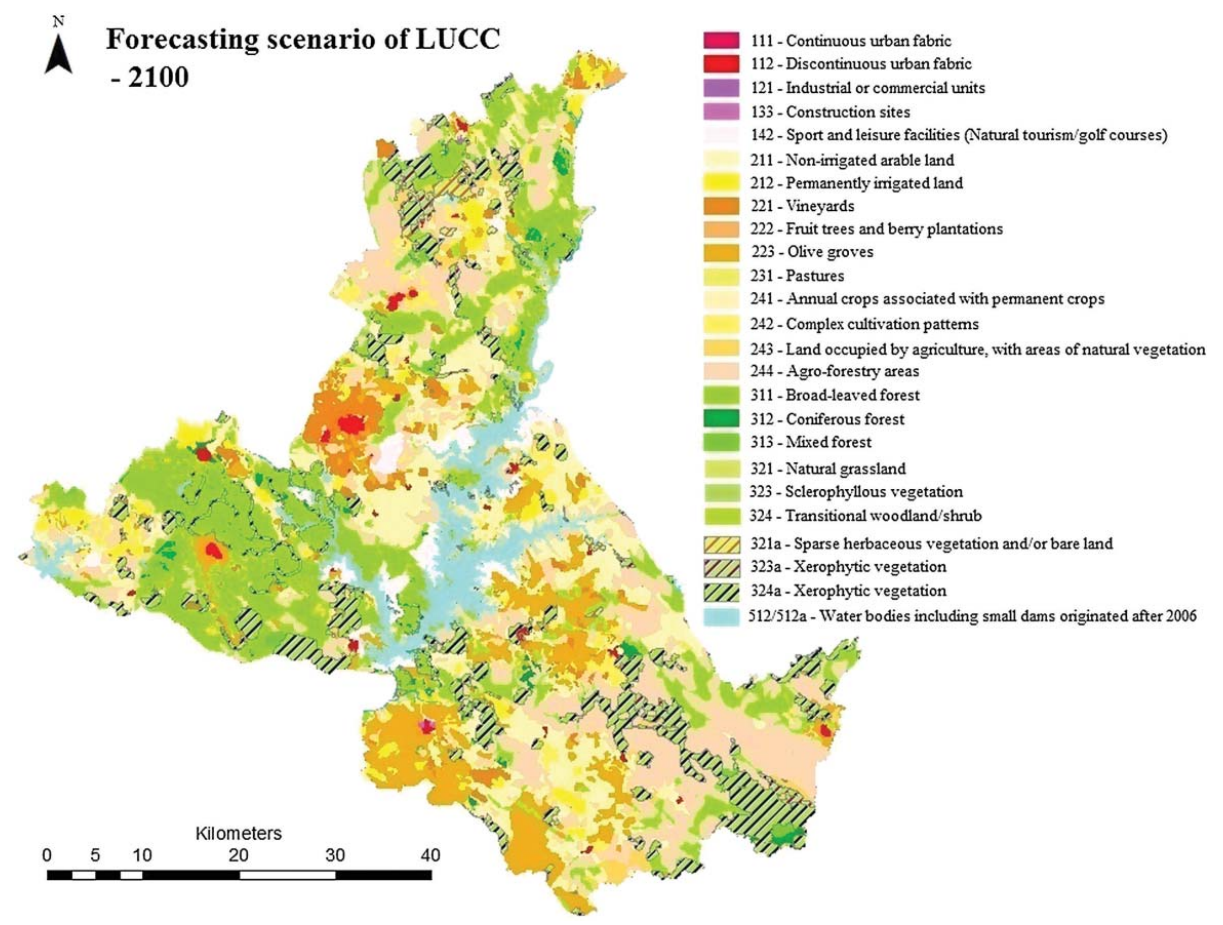

Figure 4. Forecasting scenario of the land-use/cover change for 2100. (See online colour version for full interpretation.)

possible land abandonment, irrigation is a good strategy to diversify crop production and potentially increase income (Mira da Silva et al. 2001). The expansion of natural tourism and golf areas is also occurring in the region, and some of the projects have already begun to take advantage of the landscape created by the reservoir.

The transitional shrub/woodland is expected to increase between 2006 and 2050, especially as a result of the abandonment of some agricultural land with natural vegetation, pastures with agroforestry systems and non-irrigated areas, as reported by Jones et al. (2011). The increase in forested areas by 2050 and 2100 derives from the future expectation of forest plantations for bioenergy proposes due to a developed irrigation system and the proximity to a thermoelectric centre. Between 2050 and 2100 the transitional shrub/woodland and forested area is expected to decrease due to the conversion of some xerophytic vegetation, a result of future climate change (Santos, Forbes, and Moita 2002) and continuous touristic development (golf course areas).

\subsubsection{Soil erosion}

Considering the LUCC (which affects the $\mathrm{C}$ factor) and climate change (which affects the $\mathrm{R}$ and $\mathrm{C}$ factors), a forecasting scenario of soil erosion was developed for 2100 (Figure 6).

Comparing this forecasting scenario for 2100 with the current situation obtained for 2006 , the soil erosion rate is likely to increase in many places. The annual mean of the soil erosion for 2100, in the area surrounding Alqueva reservoir, is predicted to be 3.65 


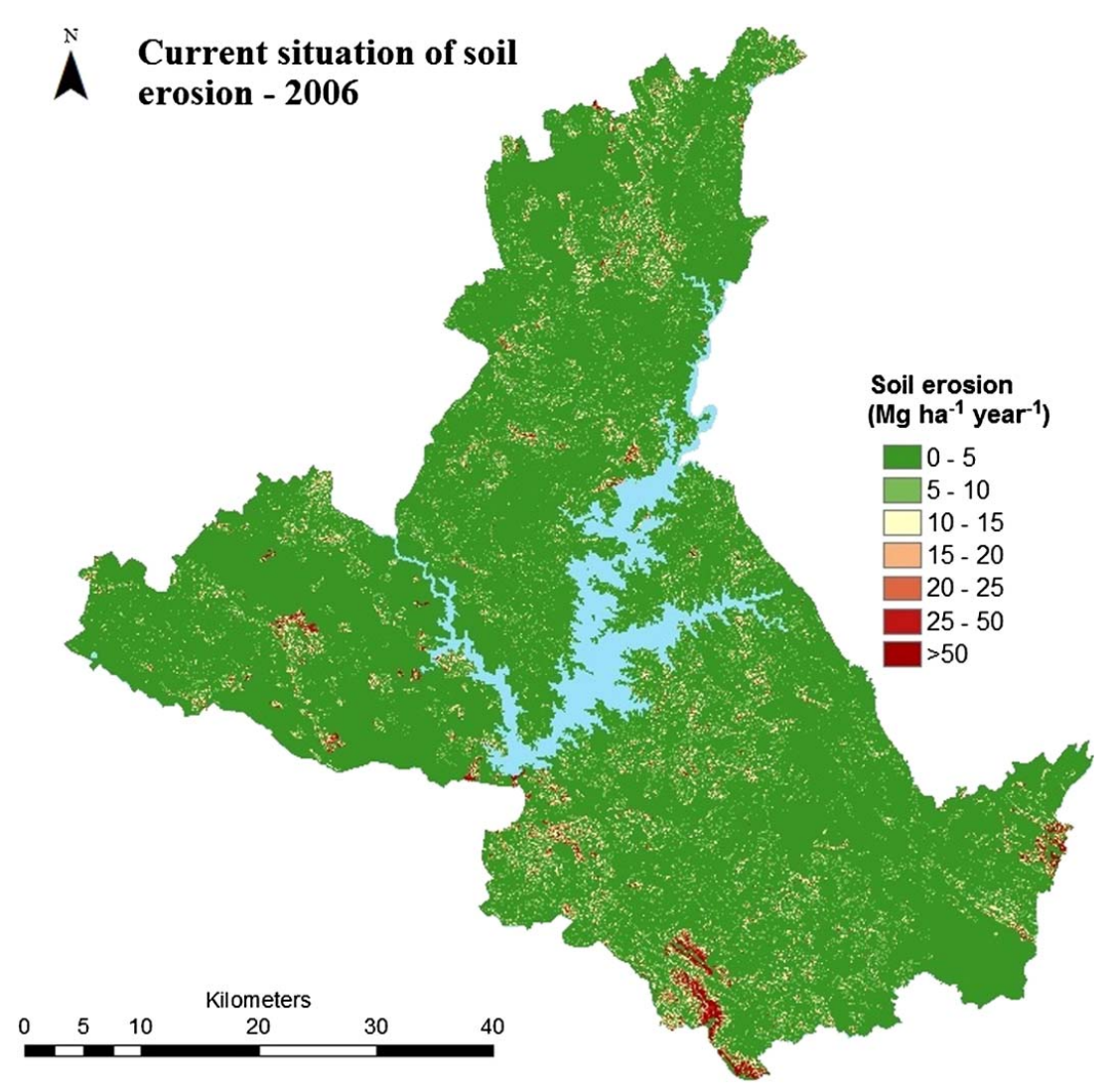

Figure 5. Estimated soil erosion for 2006. (See online colour version for full interpretation.)

$\mathrm{Mg} \mathrm{ha}^{-1}$, representing an increase of more than $100 \%$ when compared with the mean value for 2006 . The soil erosion in this scenario is predicted to be higher than $50 \mathrm{Mg} \mathrm{ha}^{-1}$ year $^{-1}$ for $5 \%$ of the surrounding area and these values are primarily found in the southeast.The intensification of this problem in that area is primarily associated with the change from transitional woodland/shrub and Sclerophyllous vegetation to xerophytic vegetation cover and a decrease in forest density. According to Klooster (2003), xerophytic vegetation areas are prone to sheet and gully erosion. However, in the western part of the reservoir the forest density is expected to increase. Additionally, the increase of some land-use types such as vineyards, olive groves and irrigated agriculture contributes to intensifying soil erosion in the future, as it reduces the soil vegetation cover (lower $\mathrm{C}$ factor).

\subsection{Backcasting scenario - sustainable land management}

The backcasting scenario for 2100 , considering the SLM implementation, is represented in Figure 7. It is evident that the implementation of these common practices can effectively decrease soil erosion if specifically applied on the land-use types with less vegetation protection. As interpreted from a comparison of scenarios for 2100 with and without SLM, the areas with an erosion risk greater than $50 \mathrm{Mg} \mathrm{ha}^{-1}$ per year should use 


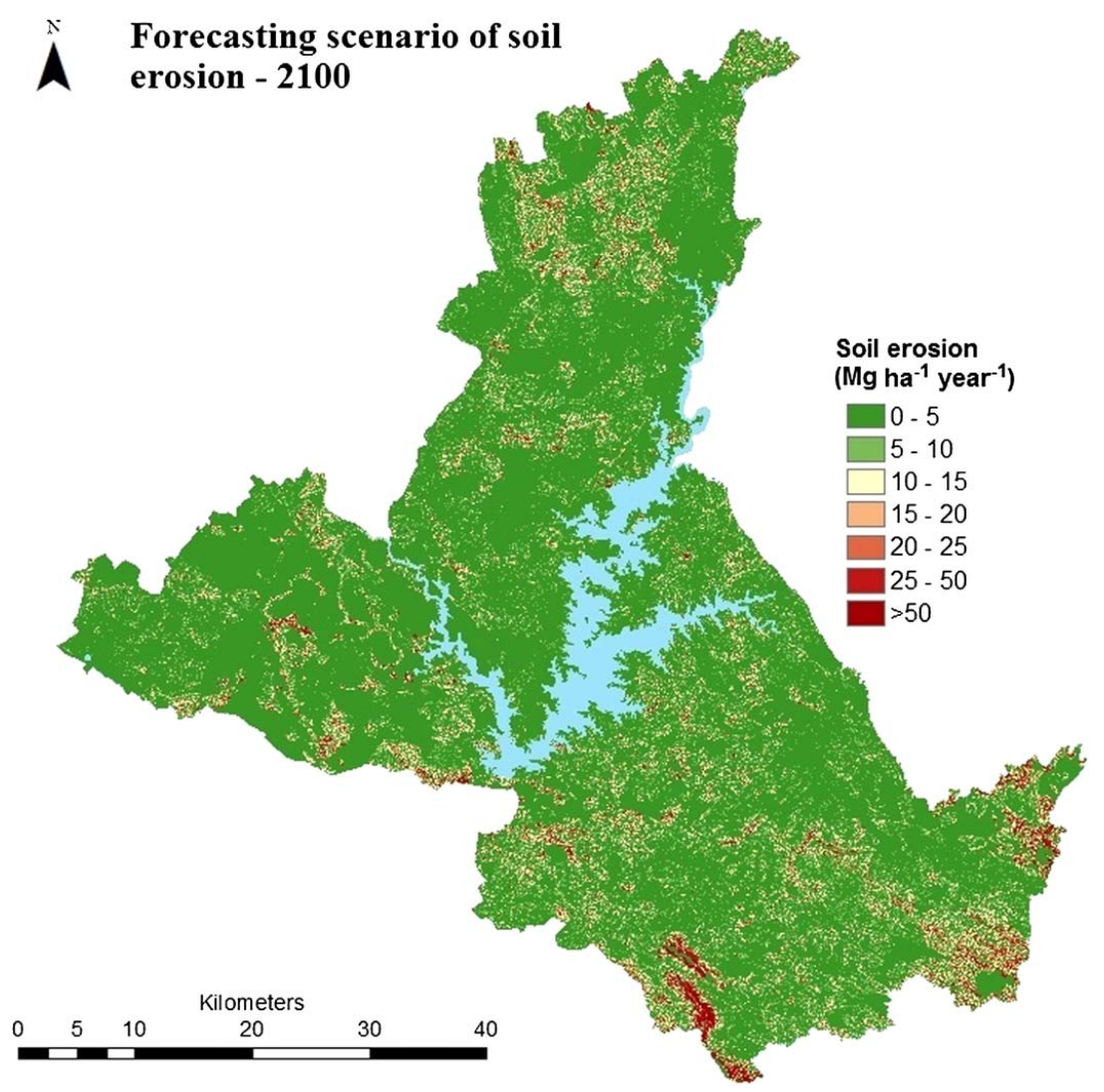

Figure 6. Forecasting scenario of soil erosion for 2100, accounting for climate and land-use/cover changes. (See online colour version for full interpretation.)

SLM practices. The estimated mean value of the annual soil erosion for 2100 with SLM was $2.27 \mathrm{Mg} \mathrm{ha}^{-1}$, a decrease of approximately $38 \%$ compared with the 2100 scenario without SLM.

Despite the reduction in soil erosion for 2100 with SLM, the mean value of soil erosion is greater than in the 2006 scenario $\left(1.78 \mathrm{Mg} \mathrm{ha}^{-1}\right)$, explained by the higher rainfall erosivity value ( $\mathrm{R}$ factor) expected from climate change, which increases the amount of soil erosion, even for soils that are better protected. Maeda et al. (2010) also studied the influence of climate change on soil erosion and stated the importance of possessing knowledge on climate change impacts for developing optimal conservation practices.

The SLM practices were specifically developed for the new land-use types with low vegetation protection; however, faced with climate change (as demonstrated by the resulting impact on the soil erosion map), it is important to implement other SLMs on the existing land-use types (especially pastures, annual crops, complex agricultural crops and other agriculture types with natural vegetation). Different SLM practices have been applied in Mediterranean areas and the advantageous results have been reported by WOCAT databases (Schwilch, Hessel, and Verzandvoort 2012).

A simulation model was produced for this region to easily estimate the erosion for a large number of situations, allowing for a quick and clear interpretation of the data 


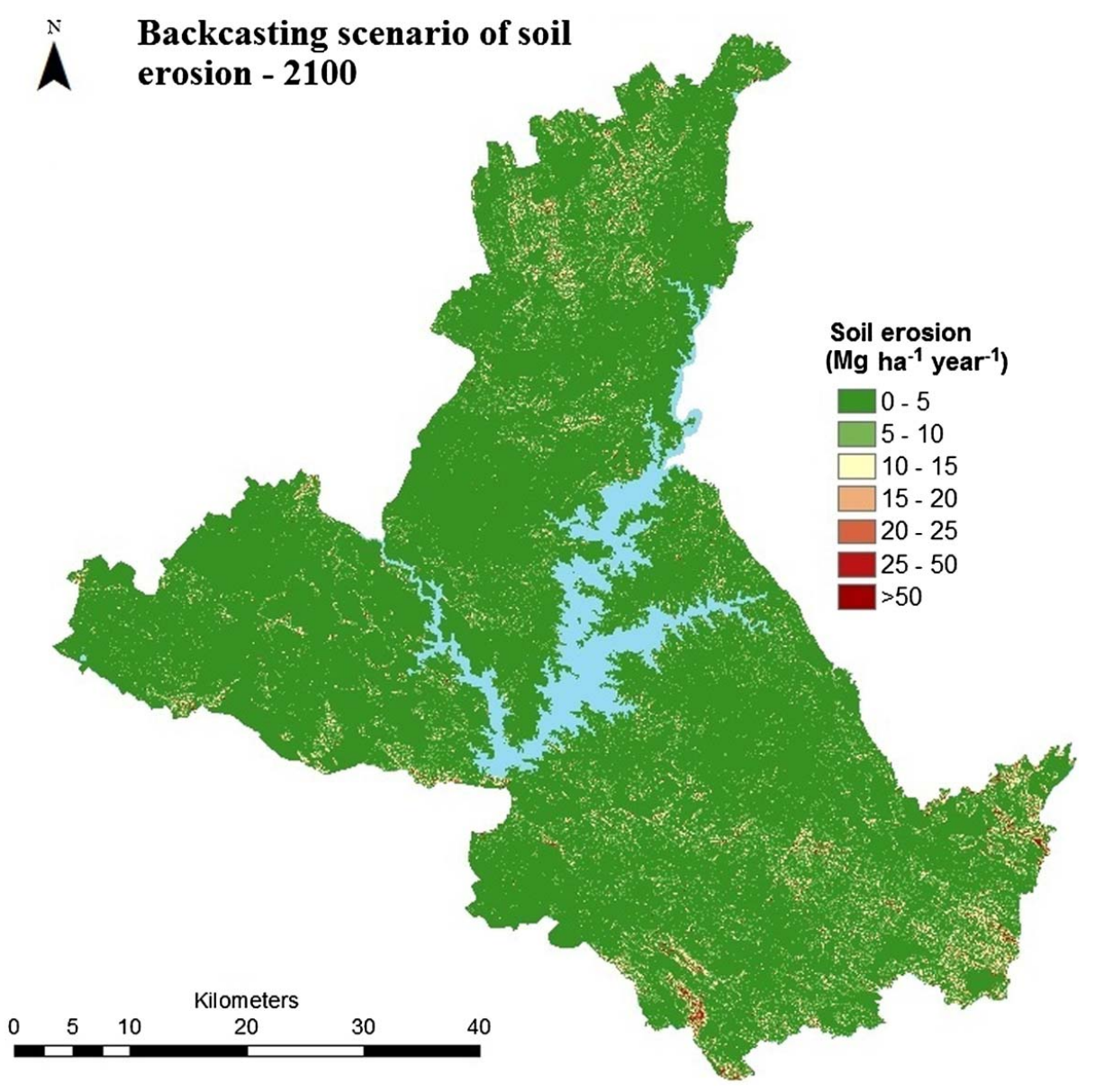

Figure 7. Backcasting scenario of soil erosion for 2100, accounting for sustainable land management practices. (See online colour version for full interpretation.)

(Panagopoulos et al. 2015). A simulation model that accounts for the problem of future LUCCs and climate change, as studied, can be incorporated into a decision support system that includes SLM practices that mitigate the impacts on soil erosion.

\section{Conclusion}

Simulation modelling using the RUSLE model in a GIS environment was successfully applied to predict the soil erosion for current conditions in the Alqueva region as well as for future scenarios that account for climate change, LUCCs and the application of SLMs. The combination of the CA-Markov model with the MCE has demonstrated its usefulness in investigating the expected LUCC, considering changes from the past and future potential directions for the Alqueva region.

Soil erosion vulnerability is expected to greatly increase by 2100 , a result of expected climate change and land-use changes, which create unfavourable conditions. However, the application of SLM practices may create conditions of stability. The creation of a 
backcasting future scenario proves the importance of the implementation of a SLM strategy in the region, when faced with the aforementioned conditions.

Using the erosion scenarios, areas of great value can be easily identified, and management control efforts can focus on these priority areas. Moreover, the present research is an effective source of awareness and empowerment for decision makers and landscape planners, through the knowledge of expected changes and their impacts. Thus, the generated scenarios have the advantage of serving as a basis for producing a decision support system for the region.

A decision support system on an individual case basis may suggest SLM alternatives and provide decision makers with expert knowledge regarding soil erosion control concerns in land management choices to protect soil resources and prolong the lifetime of the studied reservoir. Decision makers can delineate site-specific and restrictive practices, develop sustainable strategies and provide support to property owners through conservation techniques and ecologically responsible farming.

\section{Acknowledgements}

This work was supported by the Foundation for Science and Technology under grants PTDC/AACAMB/102173/2008 and SFRH/BD/69548/2010.

\section{Disclosure statement}

No potential conflict of interest was reported by the authors.

\section{ORCID}

Thomas Panagopoulos (1) http://orcid.org/0000-0002-8073-2097

\section{References}

Alpert, P., T. Ben-Gai, A. Baharad, Y. Benjamini, D. Yekutieli, M. Colacino, L. Diodato, et al. 2002. "The Paradoxical Increase of Mediterranean Extreme Daily Rainfall in Spite of Decrease in Total Values." Geophysical Research Letters 29 (11): 31.1-31.4. doi:10.1029/ $2001 \mathrm{GL} 013554$.

Arvela, A.S., T. Panagopoulos, A. Cakula, V. Ferreira, and J.C. Azevedo. 2012. "Analysis of Landscape Change Following the Construction of the Alqueva Dam, Southern Portugal Approach and Methods." In Recent Researches in Environmental Science \& Landscaping, edited by J. Burley, L. Loures, and T. Panagopoulos, 42-47. Faro: WSEAS Press.

Bakker, M., G. Govers, A. Doorn, F. Quetier, D. Chouvardas, and M. Rounsevell. 2008. "The response of soil erosion and sediment export to land-use change in four areas of Europe: The importance of landscape pattern." Geomorphology 98: 213-226.

Beasley, D., L. Huggins, and E. Monke. 1980. "ANSWERS: A Model for Watershed Planning." Transactions of the ASAE 23 (4): 938-944. doi: 10.13031/2013.34692.

Bhandari, K., J. Aryal, and R. Darnsawasdi. 2015. "A Geospatial Approach to Assessing Soil Erosion in a Watershed by Integrating Socio-Economic Determinants and the RUSLE Model." Natural Hazards 75 (1): 321-342.

Blavet, D., G. De NoniLe, Y. Bissonnais, M. Leonard, L. Maillo, J.Y. Laurent, J. Asseline, J.C. Leprun, M.A. Arshad, and E. Roose. 2009. "Effect of Land Use and Management on the Early Stages of Soil Water Erosion in French Mediterranean Vineyards." Soil \& Tillage Research 106: $124-136$.

Borges, P.J., R. Fragoso, J. Garcia-Gonzalo, J.G. Borges, S. Marques, and M.R. Lucas. 2010. "Assessing Impacts of Common Agricultural Policy Changes on Regional Land Use Patterns 
With a Decision Support System: An Application in Southern Portugal.” Forest Policy and Economics 12: 111-120.

Cantón, Y., A. Solé-Benet, J. de Vente, C. Boix-Fayos, A. Calvo-Cases, C. Asensio, and J. Puigdefábregas. 2011. "A Review of Runoff Generation and Soil Erosion Across Scales in Semiarid Southeastern Spain." Journal of Arid Environments 75: 1254-1261.doi:10.1016/j. jaridenv.2011.03.004.

CCDRA. 2001. Regional Plan of the Alqueva's Surrounding Region - PROZEA, Land Use Plan of Alqueva and Pedrógão Reservoirs - POAAP. Évora: Commission of Coordination and Development of Alentejo Region.

Chen, Y., J. Yu, and S. Khan. 2010. "Spatial Sensitivity Analysis of Multi-Criteria Weights in GISBased Land Suitability Evaluation." Environmental Modelling \& Software 25 (12): $1582-1591$.

Desmet, P.J.J., and G. Govers, 1996. "A GIS Procedure for Automatically Calculating the USLELS Factor on Topographically Complex Landscape Units."Journal of Soil and Water Conservation 51 (5): 427-433.

FAO. 2006. "World Reference Base for Soil Resources. A Framework for International Classification, Correlation and Communication." World Soil Resources Reports, 103. Rome: FAO.

Ferreira, V., and T. Panagopoulos. 2014. "Seasonality of Soil Erosion Under Mediterranean Conditions at the Alqueva Dam Watershed." Environmental Management 54 (1):67-83. http:// dx.doi.org/10.1007/s00267-014-0281-3.

Ferreira, V., T. Panagopoulos, R. Andrade, C. Guerrero, and L. Loures. 2015a. "Spatial Variability of Soil Properties and Soil Erodibility in the Alqueva Dam Watershed, Portugal."Solid Earth 6: 383-392. http://dx.doi.org/10.5194/se-6-383-2015.

Ferreira, V., T. Panagopoulos, and A. Cakula. 2013. "Prediction of Seasonal Soil Erosion Risk at the AlquevaDam Watershed, Portugal." Fresenius Environmental Bulletin 22: 1997-2005.

Ferreira, V., T. Panagopoulos, A. Cakula, R. Andrade, and A. Arvela. 2015b. "Predicting Soil Erosion After Land Use Changes for Irrigating Agriculture in a Large Reservoir of Southern Portugal."Agriculture and Agricultural Science Procedia 4: 40-49. http://dx.doi.org/10.1016/j. aaspro.2015.03.006.

Haregeweyn, N., J. Poesen, G. Verstraeten, G. Govers, J. de Vente, J. Nyssen, J. Deckers, and J. Moeyersons. 2013. "Assessing the Performance of a Spatially Distributed Soil Erosion and Sediment Delivery Model (WATEM/SEDEM in Northern Ethiopia." Land Degradation \& Development 24: 188-204. doi:10.1002/ldr.1121.

IGEO. 2012. Corine Land Cover - vector data. Instituto Geográfico Português. Lisboa. http://dgter ritorio.pt/e-IGEO/egeo_downloads.htm

Jones, N., J. de Graaff, I. Rodrigo, and F. Duarte. 2011. "Historical Review of Land Use Changes in Portugal (Before and After EU Integration in 1986) and Their Implications for Land Degradation and Conservation, with a Focus on Centro and Alentejo Regions." Applied Geography 31 (3): 1036-1048. doi:10.1016/j.apgeog.2011.01.024.

Kamusoko, C., M. Aniya, B. Adi, and M. Manjoro. 2009. "Rural Sustainability Under Threat in Zimbabwe e Simulation of Future Land Use/cover Changes in the Bindura District Based on the Markov-Cellular Automata Model." Applied Geography 29: 435-447.

Klooster, D. 2003. "Forest Transitions in Mexico: Institutions and Forests in a Globalized Countryside." Professional Geographer 55 (2): 227-237. doi:10.1111/0033-0124.5502010.

Koomen, E., J. Stillwell, A.Bakema, and H.J. Scholten, eds. 2007. Modeling Land-use Change: Progress and Applications. Dordrecht: Springer. Vol. 90 of the GeoJournal Library.

Kosmas, C., N. Danalatos, L.H. Cammeraat, M. Chabart, J. Diamantopoulos, R. Farand, L. Gutierrez, and A. Jacob. 1997. "The Effect of Land Use on Runoff and Soil Erosion Rates Under Mediterranean Conditions." Catena 29: 45-59.

Lal, R., J.A. Delgado, P.M. Groffman, N. Millar, C. Dell, and A. Rotz. 2011. "Management to Mitigate and Adapt to Climate Change." Journal of Soil and Water Conservation 66: 276-285. doi:10.2489/jswc.66.4.276.

Leh, M., S. Bajwa, and I. Chaubey. 2013. "Impact of Land Use Change on Erosion Risk: and Integrated Remote Sensing Geographic Information System and Modeling Methodology." Land Degradation \& Development 24: 409-421.

Ligtenberg, A., M. Wachowicz, A.K. Bregt, A. Beulens, and D.L. Kettenis. 2004. "A Design and Application of a Multi-agent System for Simulation of Multi-Actor Spatial Planning." Journal of Environmental Management 72:43-55. 
Lindim, C., J.L. Pinho, and J.M.P. Vieira. 2011. "Analysis of Spatial and Temporal Patterns in a Large Reservoir Using Water Quality and Hydrodynamic Modeling." Ecological Modelling 222 (14): 2485-2494. doi: 10.1016/j.ecolmodel.2010.07.019.

Maeda, E.E., P. Pellikka, M. Siljander, and B.J.F. Clark. 2010. "Potential Impacts of Agricultural Expansion and Climate Change on Soil Erosion in the Eastern Arc Mountains of Kenya." Geomorphology 123 (3-4): 279-289. doi: :10.1016/j.geomorph.2010.07.019.

Millward, A.A., and J.E. Mersey. 1999. "Adapting the RUSLE to Model Soil Erosion Potential in a Mountainous Tropical Watershed." Catena 38 (2): 109-129.

Mira da Silva, L., J.R. Park, J.D.H. Keatinge, and P.A. Pinto. 2001. "The Use of the DSSIPM in the Alentejo Region of the Southern Portugal." Agricultural Water Management 51 (3): 203-215.

Mitas, L., and H. Mitasova. 1998. "Distributed Soil Erosion Simulation for Effective Erosion Prevention.” Water Resources Research 34 (3): 505-516. doi: 10.1029/97WR03347.

Mitasova, H., J. Hofierka, M. Zlocha, and L.R. Iverson. 1996. "Modelling Topographic Potential for Erosion and Deposition Using GIS." International Journal of Geographical Information Systems 10: 629-641.

Morgan, R.P.C. 2005. Soil Erosion and Conservation. Oxford: Blackwell Publishing.

Morgan, R.P.C., J.N. Quinton, R.E. Smith, G. Govers, J.W.A. Poesen, K. Auerswald, G. Chisci, D. Torri, and M.E. Styczen. 1998. "The European Soil Erosion Model (EUROSEM): A Dynamic Approach for Predicting Sediment Transport from Fields and Small Catchments." Earth Surface Processes and Landforms 23: 527-544.

Myint, S.W., and L. Wang. 2006. "Multicriteria Decision Approach for Land Use Land Cover Change Using Markov Chain Analysis and a Cellular Automata Approach." Canadian Journal of Remote Sensing 32(6): 390-404.

Nainggolan, D., M. Termansen, L. Fleskens, K. Hubacek, M. Reed, J. Vente, and C. Boix-Fayos. 2012. "What Does the Future Hold for Semi-arid Mediterranean Agro-ecosystems? Exploring Cellular Automata and Agent-Based Trajectories of Future Land-Use Change." Applied Geography 35 (1-2): 474-490. doi:10.1016/j.apgeog.2012.09.007.

Nearing, M., G. Foster, L. Lane, S. Finkner. 1989. "A Process-based Soil Erosion Model for USDA Water Erosion Prediction Project Technology." Transaction of the ASAE 32 (5): 1587-1593.

Nearing, M.A., F.F. Pruski, and M.R. O’Neal. 2004. "Expected Climate Change Impacts on Soil Erosion Rates: A Review." Journal of Soil and Water Conservation 59 (1): 43-50.

Palacios-Agundez, I., I. Casado-Arzuaga, I. Madariaga, and M. Onaindia. 2013. "The Relevance of Local Participatory Scenario Planning for Ecosystem Management Policies in the Basque Country, Northern Spain.” Ecology and Society 18(3): 7. http://dx.doi.org/10.5751/ES-05619-180307.

Panagopoulos, T., and M.D.C. Antunes. 2008. "Integrating Geostatistics and GIS for Assessment of Erosion Risk on Low Density Quercussuber Woodlands of South Portugal." Arid Land Research and Management 22(2): 159-177. http://dx.doi.org/10.1080/15324980801958000.

Panagopoulos, T., and A.P. Barreira. 2012. "Shrinkage Perceptions and Smart Growth Strategies for the Municipalities of Portugal." Built Environment 38: 276-292. http://dx.doi.org/10.2148/ benv.38.2.276.

Panagopoulos, T., A. Cakula, V. Ferreira, and A. Arvela. 2015. "Simulation Model for Predicting Soil Erosion in a Large Reservoir of Southern Portugal." International Journal of Sustainable Agricultural Management and Informatics 1 (1): 3-25. http://dx.doi.org/10.1504/ IJSAMI.2015.069043.

Panagopoulos, T., J. Jesus, M.D.C. Antunes, and J. Beltrão. 2006. "Analysis of Spatial Interpolation for Optimising Management of a Salinized Field Cultivated with Lettuce."European Journal of Agronomy 24: 1-10. http://dx.doi.org/10.1016/j.eja.2005.03.001.

Panagos, P., K. Meusburger, C. Ballabio, P. Borrelli, C. Alewell. 2014. "Soil Erodibility in Europe: A High-resolution Dataset Based on LUCAS." Science of Total Environment 479-480:189-200. doi:10.1016/j.scitotenv.2014.02.010.

Pandey, A., V.M. Chowdary, and B.C. Mal. 2007. "Identification of Critical Erosion Prone in the Small Agricultural Watershed Using USLE, GIS and Remote Sensing." Water Resources Management 21: 729-746.

Parker, D.C., S.T. Manson, M.A. Janssen, M.J. Huffmann, and P. Deadman. 2003. "Multi-agent Systems for the Simulation of Land-use and Land-cover Change: A Review." Annals of the Association of American Geographers 93 (2): 314-337. doi: 10.1111/1467-8306.9302004. 
Peterson, G.D., G.S. Cumming, and S.R. Carpenter. 2003. "Scenario Planning: A Tool for Conservation in an Uncertain World." Conservation Biology 17: 358-366. doi: 10.1046/ j.1523-1739.2003.01491.x.

Prasannakumar, V., R. Shiny, N. Geetha, and H. Vijith. 2012. "Spatial Prediction of Soil Erosion Risk by Remote Sensing, GIS and RUSLEApproach: A Case Study of Siruvani River Watershed in Attapady Valley, Kerala, India." Environmental Earth Sciences 64 (4):965-972. doi: 10.1007/s12665-011-0913-3.

Quist, J., and P. Vergragt. 2006. "Past and Future of Backcasting: The Shift to Stakeholder Participation and a Proposal for a Methodological Framework." Futures 38: 1027-1045. doi: 10.1016/j.futures.2006.02.010.

Renard, K.G., G.R. Foster, G.A. Weesies, D.K. McCool, and D.C. Yoder. 1997. Predicting Soil Erosion by Water: A Guide to Conservation Planning with the Revised Universal Soil Loss Equation (RUSLE). Agric. Handbook No 703. Washington, DC: USDA.

Saaty, T.L. 2004. "Decision Making - The Analytic Hierarchy and Network Process (AHP/ANP)." Journal of Systems Science and Systems Engineering 13 (1): 1-35.

Salvati, L., and A. Colantoni. 2015. "Land Use Dynamics and Soil Quality in Agro-forest Systems: A Country-scale Assessment in Italy." Journal of Environmental Planning and Management 58 (1): 175-188. doi:10.1080/09640568.2013.849235.

Sanches, R., and J.O. Pedro. 2007. Alqueva, Empreendimento de Fins Múltiplos. Beja, Portugal: EDIA.

Santos, F.D., K. Forbes, and R. Moita. 2002. "Climate Change in Portugal." Scenarios, Impacts and Adaptation Measures - SIAM Project. Lisbon: Gradiva.

Schwartz, P. 1996. The Art of the Long View: Planning for the Future in an Uncertain World. New York: Currency Doubleday.

Schwilch, G., R. Hessel, and S. Verzandvoort. 2012. DESIRE for Greener Land. Options for Sustainable Land Management in Drylands. Bern: University of Bern.

Terranova O., L. Antronico, R. Coscarelli, and P. Iaquinta. 2009. "Soil Erosion Risk Scenarios in the Mediterranean Environment Using RUSLE and GIS: An Application Model for Calabria (southern Italy)." Geomorphology 112: 228-245. doi: 10.1016/j.geomorph.2009.06.009.

Tong, S.T.Y., Y. Sun, T. Ranatunga, J. He, and Y.J. Yang. 2012. "Predicting Plausible Impacts of Sets of Climate and Land Use Change Scenarios on Water Resources." Applied Geography 32: 477-489. doi:10.1016/j.apgeog.2011.06.014.

Veldkamp, A., and E.F. Lambin. 2001. "Predicting Land-use Change." Agriculture, Ecosystems and Environment 85: 1-6.

Verburg, P.H., P.P. Schot, M.J. Dijst, and A. Veldkamp. 2004. "Land Use Change Modelling: Current Practice and Research Priorities." GeoJournal 61(4): 309-324.

Volk, M., M. Möller and D. Wurbs. 2010. "A pragmatic approach for soil erosion risk assessment within policy hierarchies". Land Use Policy 27: 997-1009.

Wang, Y.Q., and M.A. Shao. 2013. "Spatial Variability of Soil Physical Properties in a Region of the Loess Plateau of PR China Subject to Wind and Water Erosion." Land Degradation \& Development 24: 296-304.

Wischmeier, W.H., and D.D. Smith. 1978. Predicting Rainfall Erosion Losses: A Guide to Conservation Planning. Agriculture Handbook 537. Washington, DC: Agricultural Research Service, USDA.

Wollenberg, E., D. Edmunds, and L. Buck. 2000. "Using Scenarios to Make Decisions About the Future: Anticipatory Learning for the Adaptive Co-management of Community Forests." Landscape and Urban Planning 47:65-77.

Yang, D., S. Kanae, T. Oki, and T. Koike. 2003. "Global Potential Soil Erosion with Reference to Land Use and Climate Changes." Hydrological Processes 17: 2913-2928. doi: 10.1002/ hyp. 1441.

Yu, W.H., S.Y. Zang, C.S. Wu, W. Liu, and X.D. Na. 2011. "Analyzing and Modeling Land Use Land Cover Change (LUCC) in the Daqing City, China." Applied Geography 31(2): 600-608. doi:10.1016/j.apgeog.2010.11.019. 